\title{
Diyabetik ayak enfeksiyonları
}

\author{
Diabetic foot infection
}

\author{
Öner Şavk, Mutlu Çobanoğlu, Ali Şişman \\ Adnan Menderes Üniversitesi Tıp Fakültesi, Ortopedi ve Travmatoloji Anabilim Dalı, Aydın
}

\begin{abstract}
Diyabetik ayak, tüm dünyada sıklığı artan, hayat kalitesini düşüren, önemli bir mortalite ve morbidite nedenidir. Etkili kan şekeri kontrolü, düzenli ayak muayenesi, uygun ayakkabı seçimi ve hasta eğitimi ile hastalığı ciddi boyutlara ulaşmadan önlemek mümkündür. Önlenemeyen hastalıklar ayakta; enfeksiyon, ülserasyon, yumuşak doku ve kemik destrüksiyonu gibi farklı klinik tablolara yol açabilir. Tedavide multidisipliner yaklaşım gereklidir. Konservatif tedavi seçenekleri öncelikli tercih olup, ileri olgularda basit debridmandan major amputasyona kadar genişleyebilen cerrahi yaklaşımlar uygulanabilir. Amputasyonların düşünüldüğü kadar masum olmadığı ve mortaliteyi artırdığı bilinmeli, tedavi seçimleri hastaya göre belirlenmelidir.
\end{abstract}

Anahtar sözcükler: diyabetik ayak; önlem; tedavi

\section{NEDEN ORTAYA ÇIKAR?}

Diyabeti olan hastaların ayak çevresinde; yaralar, enfeksiyon, kemik ve yumuşak doku kaybı yaygın olarak karşımıza çıkar. Diyabetin dünya genelinde sıklı̆ııın artması ve diyabetik hastaların yaşam ömrünün uzamasına paralel olarak, diyabetik ayağın görülme sıklığı da artmaktadır. ${ }^{[1]}$ Hayat kalitesini düşüren ve iş gücünü azaltan önemli bir problemdir. Erkeklerde, tip 2 diyabette, sigara öyküsü olanlarda ve hipertansiyonu olanlarda daha yaygındır. ${ }^{[1,2]}$ Ek olarak D vitamini düzeyindeki düşüklügüun diyabetik ayak gelişimini tetiklediği bilinmektedir. ${ }^{[3]}$

Kontrolsüz diyabete bağı bozulan glukoz metabolizması, periferik nöropati ve periferik arter hastalığına neden olur. Periferik nöropatinin neden olduğu duyu kaybı veya periferik arter hastalığına bağlı iskemi neticesinde diyabete bağlı ayak hastalıkları ortaya çıkar. Nöropati duyu sinirlerini etkileyerek his kusuruna
Diabetic foot is increasing its frequency while decreasing quality of life, since it is an important cause of morbidity and mortality in the world. Good glycemic control, regular foot examination, appropriate shoe selection and patient education can prevent the disease before it can have serious impacts. Unavoidable situations might cause foot infection, foot ulceration, soft tissue and bone destruction. For treating such cases multidisciplinary approach is important. However, priority should be given to conservative treatment options. In advanced cases, surgical approaches ranging from simple debridement to major amputation are frequently used. Amputations are not as harmless as it is thought and can increase mortality. Treatment choices should be made for each patient with appropriate care.

Key words: diabetic foot; prevention; treatment

neden olduğu gibi, otonom sinirleri etkileyerek kas disfonksiyonu, dinamik kontraktürler ve parestezilere de neden olur. ${ }^{[4]}$ Periferik nöropati ayakta deformite gelişimi ile doğrudan ilişkilidir. ${ }^{\left[{ }^{[]}\right.}$En klasik örnek kemik, eklem ve yumuşak dokunun ilerleyici tahribatına yol açarak, en sık ayak ve ayak bileğinde ortaya çıkan Charcot artropatisidir. ${ }^{[6]}$ Periferik arter hastalığı tipik olarak distal damarları etkiler. Mikrosirkülasyondaki fonksiyonel değişikliklerin yanı sıra, enfeksiyon ve ödem gibi lokal faktörler diyabetik ayak ülserinin oluşmasına zemin hazırlar. Ayak ülserleri, kronik diyabeti olan hastalarda en yaygın komplikasyonlardan biridir. Tüm diyabet hastalarının yaklaşık \%15'inde görülmektedir. ${ }^{[7]}$ Mikrovasküler dolaşım bozukluğunun zaman içerisinde ortaya çıkardığı patofizyolojik değişiklikler sonucunda, tedaviye rağmen dolaşımı yeniden sağlamak zordur. Başarılı bir revaskülarizasyondan sonra bile yara iyileşmesi sağlanamayabilir. ${ }^{[8]}$ Kronikleşen yaraların tedavisi oldukça uzun ve iyileşmesi oldukça

- İletişim adresi: Prof. Dr. Öner Şavk, Adnan Menderes Üniversitesi Tıp Fakültesi, Ortopedi ve Travmatoloji Anabilim Dalı, 09100 Aydın Tel: 0542 - 3155262 e-posta: osavk@hotmail.com

- Geliș tarihi: 29 Haziran 2020 Kabul tarihi: 21 Temmuz 2020 


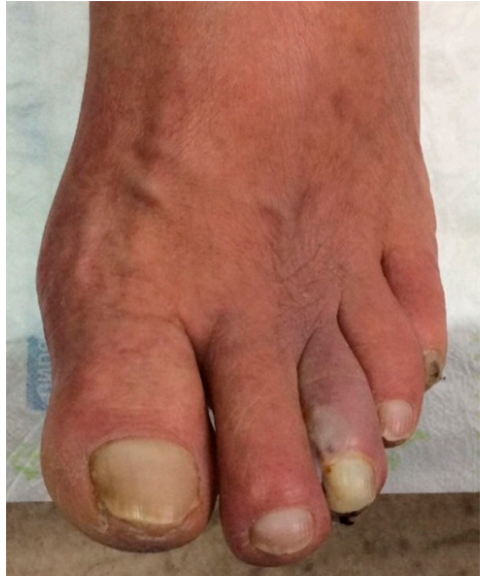

Şekil 1. Kızarıklık, su toplama ve hiperemi.

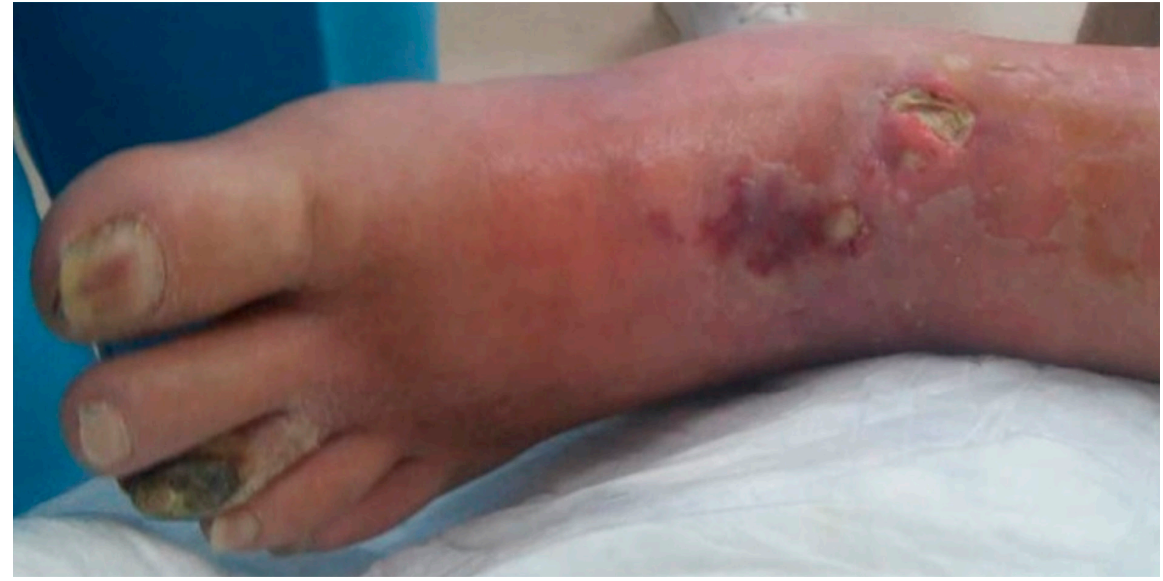

Şekil 2. Şekil 1'deki hastada üç ay sonra nekroz, hiperemide artış ve yaralar. yavaştır. İyileşmeyen diyabetik ayak ülserleri amputasyonların önemli nedenlerinin başında gelmektedir. ${ }^{[7,9]}$ Nöropati tespit edilen ve diyabetik ayak ülseri olan hastaların gelecek 10 yılda yaklaşık \%7 oranında ampute olma riski vardır. ${ }^{[10]}$ Ayrıca diyabetik hastalarda karşımıza çıkan osteomiyelitin en önemli nedeni, tedaviye dirençli veya tedavi edilmeyen ülserlerin derin dokulara yayılmasıdır. ${ }^{[11]}$

\section{NASIL TANIYALIM?}

Dikkatli bir ayak muayenesi hastalı̆ın erken tanınması açısından önemlidir. Diyabetik hastalarda her muayenede ayakta ülser ya da gangren taranmalıdır. Tırnakta veya ayakta mantar enfeksiyonu, tırnaklarda şekil bozukluğu, ciltte çatlak veya fissür, parmak aralarında maserasyon, nasır, pes kavus gibi ayak deformiteleri varlı̆̆ında ayak ülseri gelişim riski yüksektir. Muayenede ayak sırtının ısısı el ile ölçülmelidir. Ayağın soğuk olması iskemiyi işaret ederken, sıcaklık artışı, şişlik, kızarıklık ise akut enflamasyon, Charcot artropatisi veya selülitin işareti olabilir (Şekil 1 ve 2). ${ }^{[2,12]}$ Diyabetik bir hastada klinik olarak enfekte olmamış, ılık ve duyu kaybı olan bir ayağın aksi ispat edilmediği sürece, Charcot ayağı olarak kabul edilmesi gerekir (Şekil 3). ${ }^{[13]}$ Ayrıca huzursuzluk, bitkin görünüm, bilinç değişikliği, solunum sıkıntısı ve ateş gibi semptomlar hastanın genel durumunu belirlemek için yol göstericidir.

Periferik nöropati ve periferik arter hastalığının tespiti, diyabetik ayak ülserleri gelişimi için riski öngörmeye yardım eder. Periferik nöropatiyi saptamak için bazı yöntemler tariflenmiş olup, en sık kullanılan $10 \mathrm{~g}$ monofilament testidir. Amacı diyabetik ayak sorunları ortaya çıkmadan önce duyu kusurunu tespit edebilmektir.

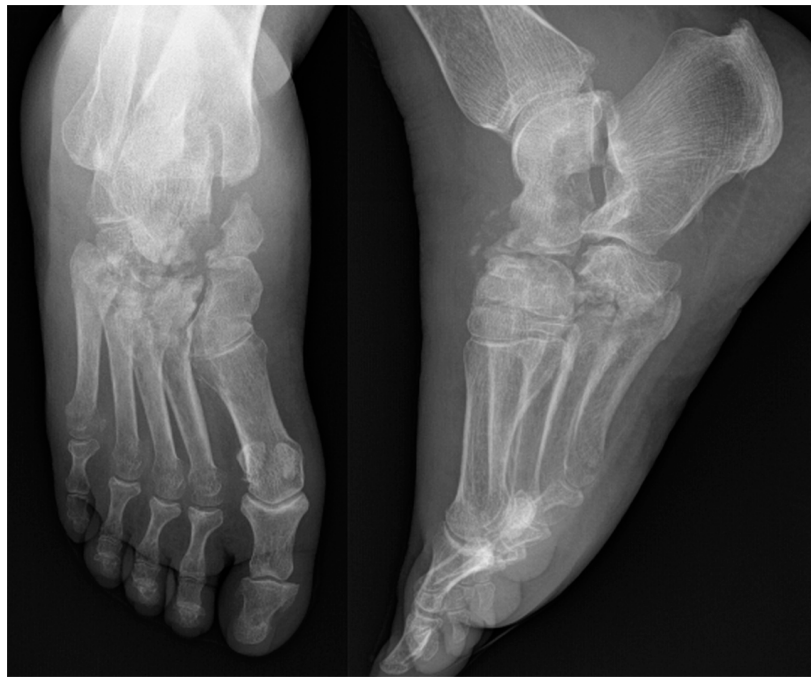

Şekil 3. Charcot ayağı.

Testte bir kez patoloji saptandıktan sonra tekrar edilmesine gerek yoktur. ${ }^{[14]}$ Intermittan kladikasyo öyküsü ve periferik nabızların değerlendirilmesi (dorsalis pedis ve tibialis posterior) periferik arter hastalığını tanımada önemli yol göstericilerdir. ${ }^{[15]}$

Diyabetik ayağa bağı osteomiyelit olgularının tanısında ilk olarak direkt grafi değerlendirilir, kanda sedimentasyon ve C-reaktif protein gibi akut faz reaktanlarının düzeyine bakılır. Klasikleşmiş tanı yöntemi; invaziv olarak alınan örneğin histopatolojik olarak incelenmesi ve kültürde üretilmesidir. Bunların yanında manyetik rezonans görüntüleme, sintigrafi ve bilgisayarlı tomografi yöntemlerinden de yararlanılabilir. Görüntüleme yöntemleri arasında spesifitesi en yüksek olanlardan birinin 99 mTc işaretlenmiş lökosit sintigrafisi olduğu gösterilmiştir. ${ }^{[16]}$ 


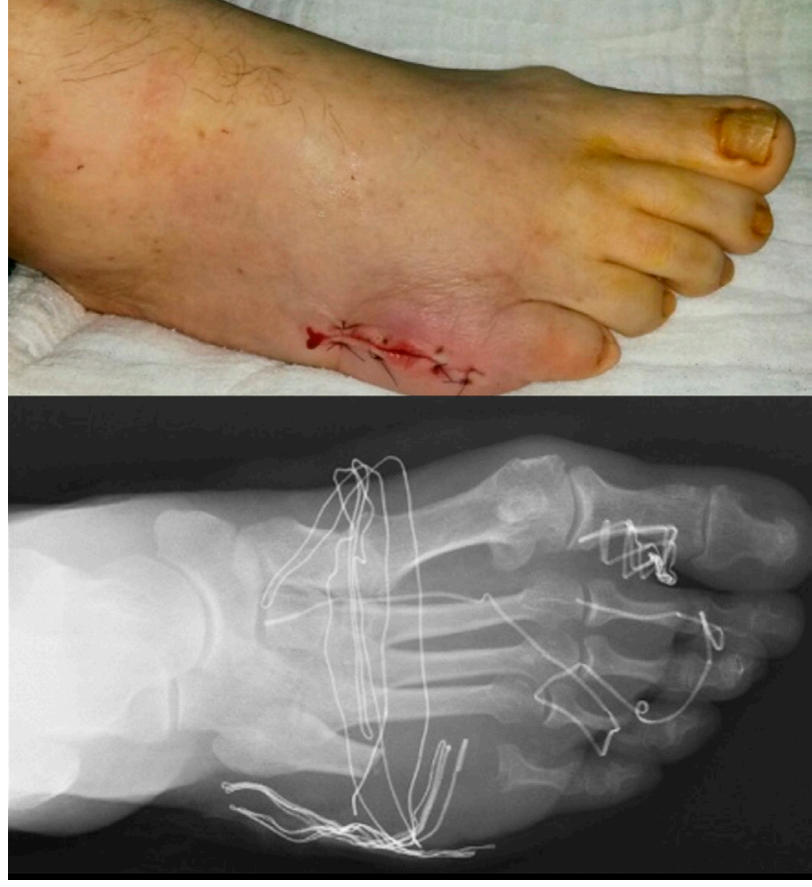

Şekil 4. Beşinci metatars başı rezeksiyonu (sınırlı cerrahi).

\section{NASIL ÖNLERIZ?}

Diyabetik ayak hastaları genellikle ağrı duyusundan yoksun olduklarından, hastalıklarının ciddiyetinin farkında değildir. Ülseri olan hastaların yaklaşık \%10'u doktor tarafından görülene kadar hastalıklarının farkına varamamaktadır. ${ }^{[2]}$ Erken tanı ve tedavi ile hastalık ciddi boyutlara ulaşmadan önlenebileceği gibi, iyileşen yaranın tekrar ortaya çıkma oranı da azalmaktadır. ${ }^{[17]}$ Bu nedenle belirli aralıklarla kontrol gereklidir. Yaşı 15 ve üzeri olan hastalara yılda bir kez ayak muayenesi yapılmalıdır. Periferik nöropati ve periferik arter hastalığı tespit edilmiş ise daha sıkı takip gerekir. Kan şekeri ve $\mathrm{HbA} 1 \mathrm{c}$ seviyesinin optimum düzeyde tutulması periferik nöropati gelişimini azaltmaktadır. ${ }^{[18]}$ Özellikle HbA1c seviyesi \%8'in üzerinde olduğunda alt ekstremitenin amputasyon riski artmaktadır. ${ }^{[19]}$

Diyabetik ayak hastalıklarının önlenmesinde en temel nokta hasta eğitimidir. Hastalara düzenli kan şekeri ölçüm ve takibinin gerekliliğinin yanında; diyet, egzersiz ve sigaradan uzak durmanın önemi benimsetilmelidir. ${ }^{[2]}$ Ayakkabı tercihi önemli yer tutmaktadır. Ayak şekline uygun ayakkabı seçimi, mutlaka çorap kullanılması ile giymeden önce ayakkabı içinde yabancı cisim araştırılması basit ama önleyici tedbirlerdir. Üç ayda bir ayakkabı uygunluğu kontrol edilmelidir. Şayet plantar ayak yaraları var ise, basıncı azaltarak iyileşmeyi hızlandıracak off-loading ayakkabılar yaptırılabilir. ${ }^{[20]}$

\section{TEDAVi}

Tedavide multidisipliner yaklaşım mutlaka gereklidir. Ayakta nasır veya artan basınç var ise, ilerlemeyi durdurmak için önleyici bakım yapılmalıdır. Diyabetik ayak ülserleri, basınçtan en fazla etkilenen metatars başı ve ayağın plantar yüzünde görülmektedir. ${ }^{[5]}$ Temel amaç yara üzerindeki basıncı düşürerek enflamasyonu azaltmak ve yara iyileşmesini hızlandırmaktır. Bu amaçla ortezler, özel ayakkabılar, yürüteçler ve ateller kullanılabilir. Diyabetik ayak yaralarının şiddeti arttıkça yara örtüleri gibi gelişmiş tedavi seçenekleri kullanılabilir. ${ }^{[21]}$

Ciddi diyabetik ayak ülserlerinde debridman önemli yer tutar. Öncelikle ülserin derinliği ve derecesi belirlenmelidir. Yüzeysel ülserasyon gibi görünen yara bazen buz dağının görünen kısmı olabilir. Debridmanın özenle yapılması, enfektif dokuların uzaklaştırılması, kanlanmanın sağlanması ve tüm nekrotik dokuların çıkarılması gerekir. Ayak duyarsız olduğundan bazen yatak başı debridmanlar yapılabilirken, ciddi olgularda ameliyathanede ve anestezi altında debridman uygulamak daha verimli olacaktır. ${ }^{[22]}$ Tecrübesiz cerrahlar tarafindan yapılan yetersiz debridmanlar sonucu, ülserlerin tekrar etme oranı ve hastanede kalış süreleri uzamaktadır. ${ }^{[23]}$ Diyabetik yaralarda enfeksiyonun tedavisi zordur. İyileşmenin gecikmesinde ve yaranın kronikleşmesinde, tıpkı ortopedik implant enfeksiyonlarında olduğu gibi biyofilm tabakanın etkili olduğu düşünülmektedir. ${ }^{[24]}$ Ancak bu konuda daha güçlü kanıtlara ihtiyaç vardır. Tedaviye dirençli, travma ile açıklanmayan, plantar yüz yerleşimli olmayan atipik ülserlerde biyopsi alınması önerilir. Bu tip lezyonların kanser öncüsü ya da metastaz olabileceği unutulmamalıdır. ${ }^{[22]}$ Diyabetik yaranın kansere dönüştüğü (özellikle skuamöz hücreli kanser) olgular bildirilmiştir. ${ }^{[25]}$

Tarihsel süreçte, yara iyileşmesini hızlandırmak ve enfeksiyonla mücadele etmek için, salin (serum fizyolojik) solüsyonları başta olmak üzere, büyüme faktörleri, elektrik stimülasyonu, doku biyomühendisliği ve deri yamaları gibi birçok yöntem denenmiştir. Bunların hiçbirinin birbirine üstünlügü tespit edilmemekle birlikte, vakum sistemleri geleneksel yöntemlere göre yara boyutunda daha fazla azalma ve daha hızlı yara iyileşmesi sağlamaktadır. ${ }^{[26,27]}$ Ülser tedavisine olası bir öncül lezyon görüldüğünde başlamalıdır. Böylece amputasyon ile sonuçlanabilecek daha ciddi ülser gelişimi önlenebilir. ${ }^{[5,21]}$ Ülser tedavisinde temel yaklaşım konservatiftir. Konservatif tedavide başarısızık, dirençli enfeksiyon ve ülserin tekrar etmesi durumunda cerrahi tedavi planlanabilir. Metatars başı rezeksiyonu (Şekil 4), rezeksiyon artroplastisi, metatarsal osteotomi, aşil tendon uzatma, gastroknemius gevşetme ve fleksör tenotomi yaygın kullanılan yöntemlerdir. ${ }^{[28]}$ Bunların dışında son basamak tedavi seçeneği amputasyonlardır. 


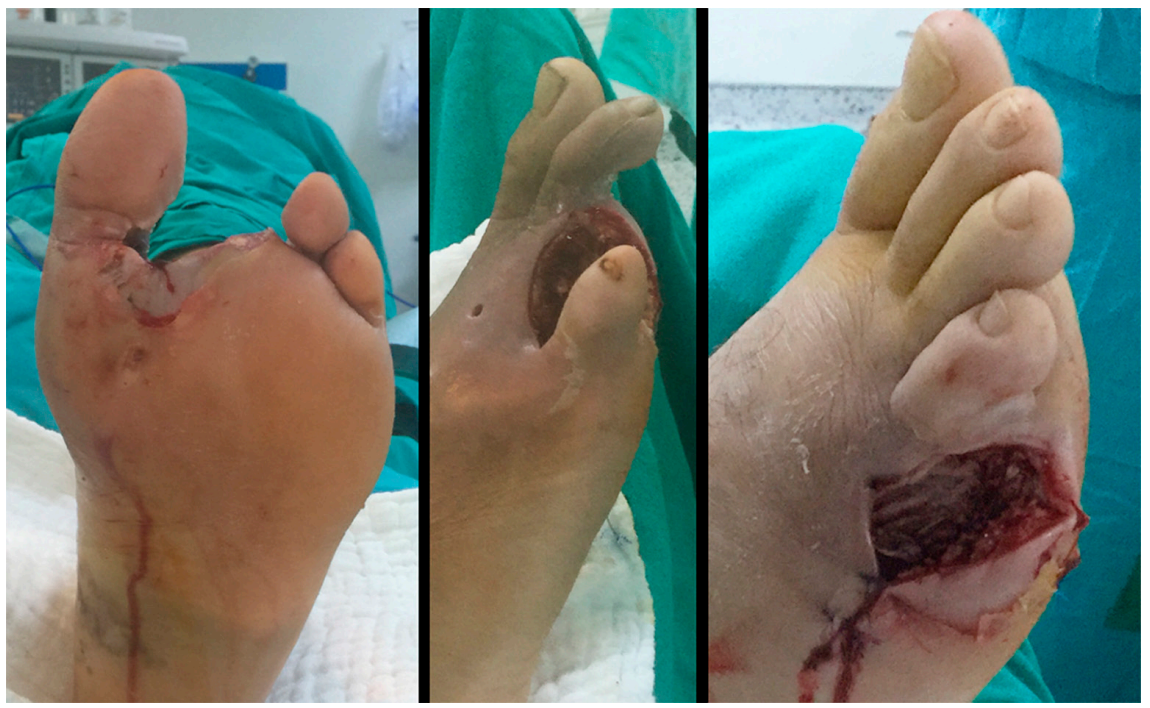

Şekil 5. Değişik şekillerde amputasyon.

Diyabetik ayak ülserleri alt ekstremite amputasyonlarının en sık nedenidir. Diyabeti olanlarda, diyabeti olmayanlara göre 22 kat daha fazla alt ekstremite amputasyon oranı saptanmıştır. ${ }^{[29]}$ Kan şekeri kontrolü, lokal yara yönetimi, damar hastalıkları ve enfeksiyonla mücadele majör amputasyonun önlenmesinde en önemli dört faktördür. ${ }^{[30]}$ Cerrahi tedavinin temel amaçları, düzeltilemeyen dokuyu etkin bir şekilde yok etmek, birincil iyileşmeyi sağlamak ve sonraki dinamik işlevselliği en üst düzeye çıkarmak için uygun prosedürü seçmektir. ${ }^{[31]}$ Ray amputasyon, transmetatarsal amputasyon, diz altı ve diz üstü amputasyonlar en yaygın kullanılan teknikler olup, bunların dışında bir çok amputasyon tekniği tarif edilmiştir (Şekil 5). Gereklilik halinde daha proksimal seviyelerden de uygulanabilir. Amputasyon bazı durumlarda kaçınılmaz olup, sanıldığı kadar masum olmadığı bilinmelidir. Özellike majör amputasyonlar sonrası hastaların yaşam süresi önemli oranda azalmaktadır. İleri yaşta; kronik böbrek yetmezliği, kardiyovasküler sistem hastalığı, periferik arter hastalığı olanlarda ve amputasyon seviyesi yükseldikçe mortalite riski artmaktadır. ${ }^{[32]}$

Metatarsların bir veya birkaçının parsiyel ya da tamamen çıkarıldığı ray amputasyonlardan sonra bile hastanın yaşam kalitesi düşmekte, yürümenin itme (push-off) fazının bozulmasına bağlı olarak, yürüyüş biyomekaniğini bozulmaktadır. ${ }^{[33]}$ Transmetatarsal amputasyon, diyabetik hastalarda oldukça sık kullanılan, fonksiyon kaybını aza indirgeyen, böylece ciddi ekstremite kaybını önleyerek yaşam kalitesini artıran değerli bir seçenektir. ${ }^{[19]}$ Diz altı amputasyon (DAA) ve diz üstü amputasyonlar (DÜA), majör amputasyonlardan en sık uygulananlardır. Amputasyon seviyesini doğru bir şekilde tespit etmek, hem tekrar ameliyat gereksinimini azaltmak, hem de daha fonksiyonel bir ekstremite bırakmak açısından önemlidir. Seviye belirlerken birçok faktör değerlendirilir ancak özellikle popliteal nabızların alınması DAA sonrası başarıda kritik öneme sahiptir. DAA ve DÜA kıyaslandığında, DÜA sonrası yara iyileşmesi daha iyi olduğundan tekrar amputasyon oranları daha düşüktür. ${ }^{[34]}$ Ancak Amputasyon seviyesi yükseldikçe ameliyat sonrası rehabilitasyon başarısı azalmaktadır. DAA uygulanan diyabetik hastalarda ilk yıl içinde ölüm oranı \%24, beş yıl içinde ölüm oranı \%66, DÜA yapılan diyabetik hastalarda ilk yıl içinde ölüm oranı \%43, beş yıl içinde ölüm oranı \%83 olarak saptanmıştır. ${ }^{[35]}$ Güdük ağrısı, phantom ağrısı ve karşı alt ekstremitede osteoartrit gelişimi majör amputasyonlardan sonra sıkça karşımıza çıkan önemli sorunlardır. ${ }^{[36]}$ Komplike diyabeti olan hastalarda, diyabeti olmayanlara göre ameliyat sonrası enfeksiyon riski yaklaşık 10 kat fazladır. ${ }^{[37]}$ Yumuşak dokuların daha az zarar gördüğü floroskopi eşliğinde uygulanan minimal invaziv yöntemler, bu konudaki tecrübeler arttıkça diyabetik ayak cerrahisinde de yaygın kullanıma girebilir. ${ }^{[38]}$

Periferik arter hastalığı, diyabetik ayak yaralarında iyileşmemenin ve amputasyona gidişin önemli bir nedenidir. Açık revaskülarizasyonun yanı sıra endovasküler tekniklerin de kullanıma girmesine rağmen, birçok hastada ağır düzeyde bozulmuş perfüzyondan dolayı hekim ve hasta çaresiz kalmaktadır. ${ }^{[13]}$ Son yıllarda yaygın kullanıma giren hiperbarik oksijenin tedavisi bazı hastalarda prognoza olumlu katkısı vardır. Periferik arter hastalığı olmayan diyabetik hastalarda; yara iyileşmesini, major ve minör amputasyon oranını 

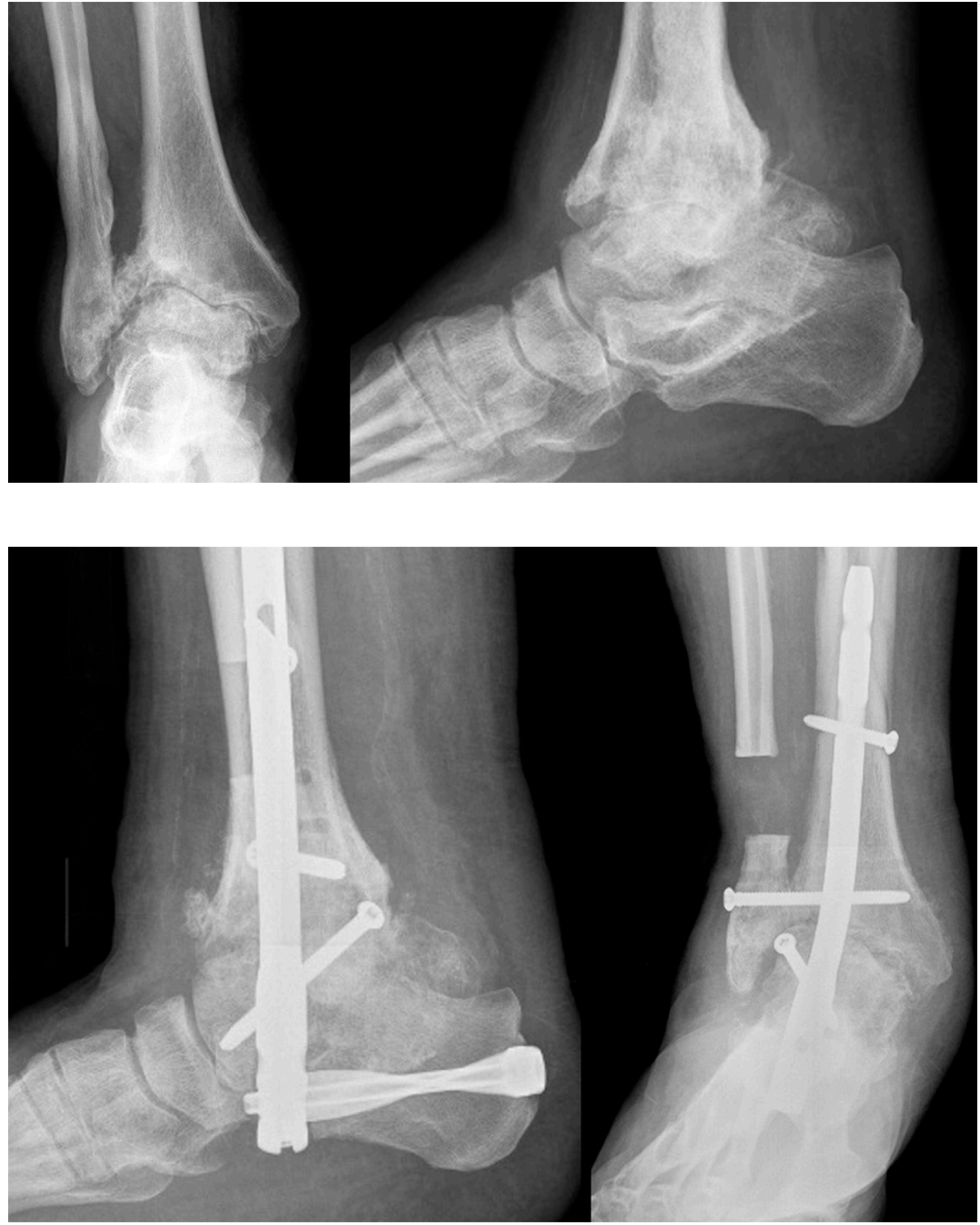

Şekil 6. Ayağın arka kısmında Charcot ayağı.

Şekil 7. Şekil 6'daki hastanın ayak bileği artrodezi sonrası. etkilememektedir. Ancak periferik arter hastalığı olan olgularda iyileşmeyi hızlandırdığı ve amputasyon oranlarını düşürrdüğü görülmüştür. ${ }^{[39,40]} \mathrm{Bu}$ nedenle ancak seçili olgularda kullanılması tavsiye edilmektedir. Bunun yanında perfüzyonun artırılması tekrar ameliyat oranını ve mortaliteyi azalttığı için cerrahi girişimlerden önce vasküler cerrahın görüşünü almak gerekir. ${ }^{[41]}$ Ayak perfüzyon düzeyinin yetersiz olması ve bir yıldan uzun süren diyabetik ayak ülseri varlığında mortalite artmaktadır. ${ }^{[42]}$

Charcot artropatisinde, öncelikle konservatif yöntemler ile eklem üzerindeki yükü azaltarak enflamatuvar süreci durdurmak ve ayakta deformite gelişmesini engellemek amaçlanır. Eklemde instabilite ve ciddi deformite geliştiğinde, yere düzgün basan fonksiyonel bir ayak sağlamak, ülser ve osteomiyelit oluşmasını engellemek için cerrahi tedavi planlanır. Cerrahide hastalığın şiddetine göre aşil tendon uzatma, ayakta ortaya çıkan ve ülser oluşumuna neden olan anormal kemik çıkıntılarının temizlenmesi ve artrodez (Şekil 6 ve 7) uygulanabilir.

Diyabetik hastalarda ayak bileği çevresinde kırık riski daha yüksektir. Tedavide konservatif yöntemler veya cerrahi tercih edilebileceği gibi, hangisinin üstün olduğuna dair yeterli veri yoktur. Tedavi kararında kırığın stabilitesi en önemli yol göstericidir. Stabil olmayan ayak bileği kırıklarında, konservatif tedavi sonrası yüksek komplikasyon oranları bildirilmiştir. ${ }^{[43,44]}$ Cerrahide; plak vida ile tespit, sirküler eksternal fiksatör, intramedüller çivileme ve primer artrodez tercih edilebilir. İleri yaş, obez ve komorbid hastalıkları fazla olan olgularda, yara yeri problemleri yüksek olduğundan, yumuşak dokuya en az zarar veren yöntemlerin seçilmesinde yarar vardır. ${ }^{[45]}$ 


\section{KAYNAKLAR}

1. Zhang P, Lu J, Jing Y, Tang Z, Zhu D, Bi Y. Global epidemiology of diabetic foot ulceration: a systematic review and metaanalysis. Ann Med 2017;49(2):106-16. Crossref

2. Mishra SC, Chhatbar KC, Kashikar A, Mehndiratta A. Diabetic foot. BMJ 2017;359:j5064. Crossref

3. Yammine $K$, Hayek F, Assi C. Is there an association between vitamin D and diabetic foot disease? A meta-analysis. Wound Repair Regen 2019;28(1):90-6. Crossref

4. Vinik Al, Maser RE, Mitchell BD, Freeman R. Diabetic autonomic neuropathy. Diabetes Care 2003;26(5):1553-79. Crossref

5. van Schie CHM. A review of the biomechanics of the diabetic foot. Int J Low Extrem Wounds 2005;4(3):160-70. Crossref

6. Frykberg RG, Belczyk R. Epidemiology of the Charcot foot. Clin Podiatr Med Surg 2008;25(1):17-28. Crossref

7. Andrews KL, Houdek MT, Kiemele LJ. Wound management of chronic diabetic foot ulcers: from the basics to regenerative medicine. Prosthet Orthot Int 2010;39(1):29-39. Crossref

8. Forsythe RO, Brownrigg J, Hinchliffe RJ. Peripheral arterial disease and revascularization of the diabetic foot. Diabetes Obes Metab 2010;17(5):435-44. Crossref

9. Singh N, Armstrong DG, Lipsky BA. Preventing foot ulcers in patients with diabetes. JAMA 2005;293(2):217-28. Crossref

10. Margolis DJ, Allen-Taylor L, Hoffstad O, Berlin JA. Diabetic neuropathic foot ulcers and amputation. Wound Repair Regen 2005;13(3):230-6. Crossref

11. Lázaro-Martínez JL, Tardáguila-García A, García-Klepzig JL. Diagnostic and therapeutic update on diabetic foot osteomyelitis. Endocrinol Diabetes Nutr 2017;64(2):100-8. Crossref

12. Walters DP, Gatling W, Mullee MA, Hill RD. The distribution and severity of diabetic foot disease: a community study with comparison to a non-diabetic group. Diabet Med 1992;9(4):354-8. Crossref

13. Markakis K, Bowling FL, Boulton AJM. The diabetic foot in 2015: an overview. Diabetes Metab Res Rev 2016;32:169-78. Crossref

14. Mayfield JA, Sugarman JR. The use of the Semmes-Weinstein monofilament and other threshold tests for preventing foot ulceration and amputation in persons with diabetes. J Fam Pract 2000;49:17-29. https://pubmed.ncbi.nlm.nih. gov/11093555/

15. Brownrigg JRW, Schaper NC, Hinchliffe RJ. Diagnosis and assessment of peripheral arterial disease in the diabetic foot. Diabet Med 2015;32(6):738-47. Crossref

16. Lauri C, Tamminga M, Glaudemans AWJM, Orozco LEJ, Erba PA, Jutte PC, Lipsky BA, IJzerman MJ, Signore A, Slart RHJA. Detection of osteomyelitis in the diabetic foot by Imaging techniques: A Systematic review and meta-analysis comparing MRI, white blood cell scintigraphy, and FDG-PET. Diabetes Care 2017;40(8):1111-20. Crossref

17. Hicks CW, Canner JK, Mathioudakis N, Lippincott C, Sherman RL, Abularrage CJ. Incidence and risk factors associated with ulcer recurrence among patients with diabetic foot ulcers teated in a multidisciplinary setting. J Surg Res 2020;246:243-50. Crossref

18. Pop-Busui R, Boulton AJM, Feldman EL, Bril V, Freeman R, Malik RA, Sosenko JM, Ziegler D. Diabetic Neuropathy: A position statement by the American Diabetes Association. Diabetes Care 2017;40:136-54. Crossref
19. Pemayun TGD, Naibaho RM, Novitasari D, Amin N, Minuljo TT. Risk factors for lower extremity amputation in patients with diabetic foot ulcers: a hospital-based case-control study. Diabet Foot Ankle 2015;6:29629. Crossref

20. Van Netten JJ, Lazzarini PA, Armstrong DG, Bus SA, Fitridge R, Harding K, Kinnear E, Malone M, Menz HB, Perrin BM, Postema K, Prentice J, Schott KH, Wraight PR. Diabetic Foot Australia guideline on foot wear for people with diabetes. J Foot Ankle Res 2018;11(1):2. Crossref

21. Blume $\mathrm{P}, \mathrm{Wu} \mathrm{S}$. Updating the Diabetic Foot Treatment Algorithm: Recommendations on Treatment Using Advanced Medicine and Therapies. Wounds 2018;30(2):29-35. https:// www.woundsresearch.com/article/updating-diabetic-foottreatment-algorithm-recommendations-treatment-usingadvanced-medicine

22. Levin ME. Foot Lesions in Patients with Diabetes Mellitus. Endocrinol Metab Clin North Am 1996;25(2):447-62. Crossref

23. Ahluwalia R, Vainieri E, Tam J, Sait S, Sinha A, Manu CA, Reichert I, Kavarthapu V, Edmonds M, Vas P. Surgical Diabetic Foot Debridement: Improving Training and Practice Utilizing the Traffic Light Principle. Int J Low Extrem Wounds 2019;18(3):279-86. Crossref

24. Lavery LA, Bhavan K, Wukich DK. Biofilm and diabetic foot ulcer healing: all hat and no cattle. Ann Transl Med 2019;7(7):159. Crossref

25. Dörr S, Lucke-Paulig L, Vollmer C, Lobmann R. Malignant Transformation in Diabetic Foot Ulcers --Case Reports and Review of the Literature. Geriatrics 2019;4(4):62. Crossref

26. Huang Q, Wang JT, Gu HC, Cao G, Cao JC. Comparison of Vacuum Sealing Drainage and Traditional Therapy for Treatment of Diabetic Foot Ulcers: A Meta-Analysis. J Foot Ankle Surg 2019;58(5):954-8. Crossref

27. Jeffcoate WJ, Price P, Harding KG. International Working Group on Wound Healing and Treatments for People with Diabetic Foot Ulcers. Wound healing and treatments for people with diabetic foot ulcers. Diabetes Metab Res Rev 2004;20(S1):S78-89. Crossref

28. Yammine K, Assi C. Surgical Offloading Techniques Should Be Used More Often and Earlier in Treating Forefoot Diabetic Ulcers: An Evidence-Based Review. Int J Low Extrem Wounds 2020;19(2):112-9. Crossref

29. Buckley CM, O'Farrell A, Canavan RJ, Lynch AD, De La Harpe DV, Bradley CP, Perry IJ. Trends in the incidence of lower extremity amputations in people with and without diabetes over a five-year period in the Republic of Ireland. PLoS ONE 2012;7(7):e41492. Crossref

30. MusuuzaJ, Sutherland BL, KurterS, Balasubramanian P, Bartels CM, Brennan MB. A systematic review of multidisciplinary teams to reduce major amputations for patients with diabetic foot ulcers. J Vasc Surg 2019;71(4):1433-46.e3. Crossref

31. Boffeli TJ, Thompson JC. Partial foot amputations for salvage of the diabetic lower extremity. Clin Podiatr Med Surg 2014;31(1):103-26. Crossref

32. Thorud JC, Plemmons B, Buckley CJ, Shibuya N, Jupiter DC. Mortality After Nontraumatic Major Amputation Among Patients with Diabetes and Peripheral Vascular Disease: A Systematic Review. J Foot Ankle Surg 2016;55(3):591-9. Crossref

33. Aprile I, Galli M, Pitocco D, Sipio ED, Simbolotti C, Germanotta M, Bordieri, Luca Padua C, Ferrarin M. Does First Ray Amputation in Diabetic Patients Influence Gait and Quality of Life? J Foot Ankle Surg 2018;57(1):44-51. Crossref 
34. Dormandy J, Heeck L, Vig S. Major amputations: clinical patterns and predictors. Semin Vasc Surg 1999;12(2):15461. https://pubmed.ncbi.nlm.nih.gov/10777243/

35. Gök Ü, Selek Ö, Selek A, Güdük A, Güner MÇ. Survival evaluation of the patients with diabetic major lower-extremity amputations. Musculoskelet Surg 2016;100(2):145-8. Crossref

36. Allami M, Faraji E, Mohammadzadeh F, Soroush MR. Chronic musculoskeletal pain, phantom sensation, phantom and stump pain in veterans with unilateral below-knee amputation. Scand J Pain 2019;19(4):779-87. Crossref

37. Wukich DK, Lowery NJ, McMillen RL, Frykberg RG. Postoperative infection rates in foot and ankle surgery: a comparison of patients with and without diabetes mellitus. J Bone Joint Surg Am 2010;92(2):287-95. Crossref

38. Botezatu I, Laptoiu D. Minimally invasive surgery of diabetic foot --review of current techniques. J Med Life 2016;9(3):249-54. https://www.ncbi.nlm.nih.gov/pmc/ articles/PMC5154308/

39. Brouwer RJ, Lalieu RC, Hoencamp R, Van Hulst RA, Ubbink DT. The need for differentiation between ischaemic and non-ischaemic diabetic foot ulcers when treating with hyperbaric oxygen therapy. Diabet Med 2019;37(2):370-1. Crossref
40. Lalieu RC, Brouwer RJ, Ubbing DT, Hoencamp R, Raab RB, Hulst RA. Hyperbaric Oxygen Therapy for Non-Ischemic Diabetic Ulcers: A Systematic Review. Wound Repair Regen 2019;28(2):266-75. Crossref

41. Aljarrah Q, Allouh MZ, Bakkar S, Aleshawi A, Obeidat $\mathrm{H}$, Hijazi E, Al-Zoubi N, Alalem H, Mazahreh T. Major lower extremity amputation: a contemporary analysis from an academic tertiary referral centre in a developing community. BMC Surg 2019;19(1):170. Crossref

42. Amadou CA, Carlier A, Amouyal C, Bourron O, Aubert C, Couture T, Fourniols E, Van GH, Rouanet S, Hartemann A. Five-year mortality in patients with diabetic foot ulcer during 2009-2010 was lower than expected. Diabetes Metab 2019;46(3):230-5. Crossref

43. Lovy AJ, James Dowdell J, Keswani A, Koehler S, Kim J, Weinfeld S, Joseph D. Nonoperative Versus Operative Treatment of Displaced Ankle Fractures in Diabetics. Foot Ankle Int 2019;38(3):255-60. Crossref

44. Manway JM, Blazek CD, Burns PR. Special Considerations in the Management of Diabetic Ankle Fractures. Curr Rev Musculoskelet Med 2018;11(3):445-55. Crossref

45. Ebaugh MP, Umbel B, Goss D, Taylor BC. Outcomes of Primary Tibiotalocalcaneal Nailing for Complicated Diabetic Ankle Fractures. Foot Ankle Int 2019;40(12):1382-7. Crossref 